\title{
Regional Order in the Arctic: Negotiated Exceptionalism
}

Heather Exner-Pirot, PhD, Strategist for Outreach and Indigenous Engagement at the University of Saskatchewan

Robert W. Murray, Managing Director at Dentons Canada LLP's Government Affairs and Public Policy Practice Group, Senior Fellow at the Macdonald-Laurier Institute, and Research Fellow at the Centre for Military, Security and Strategic Studies, University of Calgary, Canada

This article offers a theoretical explanation for what has been described as Arctic 'exceptionalism' - the successful effort to maintain cooperation in the region despite internal competition for resources and territory, and to compartmentalize Arctic relations from external geopolitical tensions. By using an English School approach to understand the Arctic, the authors describe how Arctic international society has been deliberately negotiated in a way that promotes cooperation between Arctic states, and that a rulesand norms- based order exists that serves all parties' interests well.

\footnotetext{
"The fate of each state depends on its responses to what other states do. The possibility that conflict will be conducted by force leads to competition in the arts and the instruments of force. Competition produced a tendency toward the sameness of the competitors... Contending states imitate the military innovations contrived by the country of greatest capability and ingenuity. And so the weapons of major contenders, and even their strategies, begin to look much the same all over the world." (Waltz 1979, 127)
}

In his writing on the nature of international politics, Kenneth Waltz was correct to note that states are motivated by a desire to survive and that the international balance of power was especially important in understanding and explaining how conflict could arise between states or blocs of states. Throughout the history of the state system, there has been a preoccupation with rivalry, competition, and how states perceive each other, with the majority of commentary on international politics pointing out the ever-present dangers of conflict. What is equally important to note about international politics is that states have consciously and willingly negotiated various types of international and re- 
gional order in an effort to mitigate the impact of an anarchic international system and have aligned themselves with either informal or formal organizational structures designed specifically to promote cooperation between states.

While it is true that the international system is anarchic in its structure and that states tend to behave as self-interested actors, the history of international politics has seen examples of internationalism, cooperation, and multilateralism, often characterized by states seeking opportunities to combine resources and work towards ensuring their survival through means other than conflict or coercion. Further, it is imperative to differentiate between the establishment and functioning of international order and various regional orders that have emerged at various times in world history, as regional orders tend to reflect the specific interests of like-minded states in a more concentrated way. Studies in regional order often focus on the European historical example, but more recently, regional order has been the subject of more intense scholarly study and how these regional orders relate to the larger international or world order (see Fawcett and Hurrell 1996). Much of this increased focus on regionalism and regional order comes as a result of the growth in regional cooperation and initiatives focused either on security or economic issues, such as NATO, NAFTA, the European Union, ASEAN, OAS, and others. ${ }^{1}$

The region that has received far more attention since the end of the Cold War has been the Arctic. Although the Arctic states are at odds in other parts of the world, notably over Russia's annexation of Crimea and its sponsorship of ongoing conflict in Eastern Ukraine, there has been a sense that the Arctic is somehow a 'unique' or 'exceptional' region in international affairs. There has been very minimal spillover to date in regional political relations; indeed, there have been advancements in formal cooperation in the past three years. The question has been asked: can Arctic politics be explained through the traditional lenses used to understand and explain international affairs?

This paper argues that the Arctic regional order is exceptional insofar as Arctic states and those states with involvement in the regional have worked to negotiate an order and balance of power predicated on norms such as cooperation and multilateralism. The establishment of an Arctic international society has seen great powers and smaller powers come together to form an order aimed at promoting norms and institutions not seen elsewhere in the world, though this paper notes that the Arctic is not immune from the possibility of war and conflict. By using an English School approach to understand the Arctic, we contend that Arctic international society was deliberately negotiated in a way that promotes cooperation between Arctic states, but that this order can be disrupted if Arctic international society does not take conscious steps to maintain a strong institutional framework that protects Arctic internationalism.

\footnotetext{
${ }^{1}$ Respectively, North Atlantic Treaty Organization; North American Free Trade Agreement; Association of Southeast Asian Nations; and Organization of American States.
} 


\section{Negotiating Regional Order}

One of the lasting impacts of Arctic romanticism has been a tendency of international relations scholars to apply theoretical schools of thought from the field to current Arctic politics. Oran Young summarizes this trend by arguing:

"There is a pronounced streak of romanticism in the thinking of many who take an interest in the Arctic, an attitude that encourages those affected by it to focus on the exotic and even unique properties of the physical, biological, and human systems of the region...Understandable as the resultant Arctic exceptionalism may be, it has the effect of obscuring our vision of a range of issues that are both critical to various constituencies in the Circumpolar North and of great interest to social scientists as exemplars of concerns that are generic in the sense that they arise in every corner in the world." (Young 1992, 13-14)

In examining the way scholars have approached Arctic international relations in recent years, much of the focus has been placed on aspects of traditional security studies or on the human security aspects of debates, but few approaches have made significant progress in trying to understand why international politics in the Arctic region are insulated from trends elsewhere in the world, particularly given the states involved in Arctic affairs, notably the United States and Russia.

The English School of international relations emphasizes the role of international society as a middle way of theorizing international affairs between the traditional realist conceptualizations of international politics, such as that presented by Waltz, and liberal or critical theoretical approaches that look at domestic-level or critical variables to understand global affairs. For the English School, the society of states is key to explaining state behavior, especially how states interact with one another; and more, the motives behind how and why states at times in history have willingly taken part in robust multilateral and cooperative regimes, and at others have worked together in a minimalist fashion. Robert Jackson summarizes the importance of international society as a conceptual tool for international relations by stating:

"The conceptual key to international society is the manner in which sovereign states associate and relate: the character and modus operandi of their association and relations. It is formal in a significant way: it involves procedural standards of conduct, an essential normative basis of which is international law. However, it is also substantive in an equally significant way as it involves the pragmatic encounters of the separate national interests of those same independent states which, although subject to international 
law, are still free to lay down their own foreign policies." (2000, 102)

According to the English School, states seek to ensure their survival and mitigate the effects of an anarchic international system by consenting to partake in a society of states. These societies differ in their normative frameworks and character based on a number of variables, including the great powers dominating the international system at a given time in history. The main motivator for states consenting to sacrifice elements of their independence and autonomy is their quest for survival, and according to English School theory, the ideal way for states to do this is to use international society as a means for establishing and maintaining order.

One of the most important theoretical variables in identifying the degree to which states will work together in international society and the normative or institutional framework of a given society of states is the role of great powers. It is ultimately great powers that have the most influence in negotiating, implementing and enforcing order within international society, and the relations of these powers in various systemic structures, such as bipolar, multipolar, or unipolar, determines how strong and enduring order within a society of states will be. According to Hedley Bull, great powers face a series of options available to them in their considerations of order:

"Great powers manage their relations with one another in the interests of international order by (i) preserving the general balance of power, (ii) seeking to avoid or control crises in their relations with one another, and (iii) seeking to limit or contain wars among one another. They exploit their preponderance in relation to the rest of international society by (iv) unilaterally exploiting their local preponderance, (v) agreeing to respect one another's sphere of influence, and (vi) joint action." (Bull 202, 200)

Following Bull's logic, great powers have the option to cooperate in a minimalist fashion or a more robust fashion, should they choose to do so, in the interest of maintaining order among states. An important point to highlight is that international societies are not strictly global in character, and the decisions of states, especially great powers, regarding establishing order via negotiation and the normative framework of a society of states also have consequences at the sub-global level.

In recent years, English School scholars have given more attention to the distinction between an overarching 'global' international society and 'sub-global' or 'regional' international societies. According to Yannis Stivachtis:

"Opening the regional level of analysis might have serious implications for understanding institutions and norms like sovereignty, diplomacy, balance of power and others which exist and are per- 
formed at both global and regional level as, in many cases, regions form their own sub-global (regional) international societies which co-exist with global international society." $(2015,69)$

It is therefore noteworthy to point out that, at any given time, there is both a global international society as well as a series of regional international societies, themselves consciously negotiated sub-global orders intended to better coordinate the relations between states and mitigate the effects of both anarchy, and possible global conflicts. Further, the institutions that form the normative framework of a regional international society need not be entirely consistent with those of global international society. Consequently, the relations between states at the global level may differ between those same states in regional interactions.

With eight states, multiple Indigenous groups, multilateral institutions and an emerging governance regime, and vast interest from a number of states and institutions, the Arctic is most certainly an emerging example of a regional international society (see Weinert 2014). Stivachtis furthers this claim by stating:

"Arctic international relations are a complex of political, economic, development and militaristic dimensions. Throughout the Cold War, the Arctic was a region of symbolic military competition between the United States and Soviet Union. However, post-Cold War conditions in conjunction with climate change have transformed the Arctic into an important world region in the sense that states began to assert their claims of national sovereignty over areas previously considered inaccessible. This has had important implications for the Arctic regional order." $(2015,78)$

The case for discussing Arctic exceptionalism traditionally hinges more on arguments about the Arctic being insulated from other geopolitical and international issues, particularly involving conflict, than being seen as a unique zone of cooperation. While it may be true that no region can be totally insulated from other international or global trends, it can be the case that the Arctic is 'exceptional' to the extent that the states that comprise Arctic international society have intentionally negotiated a regional order predicated on a more cooperative framework than they pursue with each other elsewhere, and have endeavored, implicitly, to compartmentalize relations there. The following section will explain in greater detail the normative composition of Arctic international society and the reasons state behavior in the region might look different, or exceptional.

\section{An Arctic International Society Emerges}

The establishment of an Arctic international society emerged, like many phenomena in contemporary international relations, at the time of the collapse of the Soviet Union. 
The negotiation of the Arctic Environmental Protection Strategy (AEPS) in 1991, and subsequently the establishment of the Arctic Council in 1996, are often pointed to as the beginning of regional state relations. However, its true origins are more closely tied to a 1987 speech in Murmansk by Soviet President Mikhail Gorbachev, to which the AEPS and Arctic Council, and many other foundational institutions of Arctic international society, were a response. It included six points:

1. A nuclear-free zone in Northern Europe.

2. Restricting naval activity in the Baltic, Northern, Norwegian and Greenland Seas, and extending confidence-building measures in these areas.

3. Peaceful cooperation in developing the resources of the North, including knowledge exchange, with specific mention of "oil and gas deposits of the shelf of our northern seas".

4. The development of scientific cooperation in the Arctic, including "questions bearing on the interests of the indigenous population of the North... and the development of cultural ties between northern peoples".

5. Cooperation in environmental protection.

6. The development of the Northern Sea Route.

Re-examining the speech, which further called for the Arctic to become a "zone of peace", there is evidence of significant continuity in regional state interests and goals over the past thirty years. Although the international system has evolved, state interests in the Arctic have remained largely intact and have led to normative institutions predicated on cooperation and multilateralism. These include: (1) efforts to maintain peace and stability in the region, echoed more contemporarily in the confidence-building efforts attempted through the Arctic Chiefs of Defense Staff meetings (though suspended after only two gatherings in 2014 after the Crimea intervention); (2) the establishment in 2015 and continuing efforts of an Arctic Coast Guard Forum; and (3) a premium placed on cooperation with regards to economic, scientific and environmentalist endeavors, manifested in the work of the Arctic Council, various scientific organizations, fishery regulations, the establishment of mandatory polar shipping guidelines, and the large number of other Arctic conferences and forums on a variety of topics. These interests have all been reiterated in the strategic objectives of the Arctic states as described in regional and national policies and speeches since 2008 (Heininen 2012), and clearly demonstrate a set of primary institutions within Arctic international society that are unique to the region and its particular political dynamics.

The institutionalized, stable, and rules-based Arctic society of states has also successfully integrated world society variables, such as NGOs, indigenous groups, and global civil society. Arctic-based organizations founded in the early 1990s include the Northern Forum, the International Arctic Science Committee (IASC), the Inuit Circumpolar Conference (now Council), the Barents Euro Arctic Council, and the University of the Arctic, alongside others. The AEPS, a Finnish initiative that included all eight states 
with Arctic territory, also made, in retrospect, a transformational move by including Indigenous groups formally within the institution, a trend that was then replicated in the Arctic Council.

If Russia and the Murmansk speech provided space for the development of an Arctic international society, it is Finland and Canada, both middle powers that are generally attributed with leading its formalization, at least in the 1990s (Huebert 1998; Keskitalo 2004; English 2013). This is consistent with Martin Wight's view of the role middle powers play in the formation and conduct of societies of states (1978). It is notable that the United States played a limited role in the establishment of the Arctic Council, other than to circumscribe its mandate, such as the proscription on discussions of a military nature and defined financial contributions to the forum, at a time when the United States was trying to taper the proliferation and scope of international multilateral institutions (English 2013). Individual Americans, however, played key roles in regionalization processes. U.S. government participation in the Arctic Council was very much a concession to Canadian appeals, and was contingent on the Council not dealing with matters of military security or demanding defined contributions, and the adoption of a consensus based decision-making structure (English 2013; Bloom 1999). The U.S. also conceded the inclusion of Indigenous organizations as Permanent Participants, and the mandate for sustainable development, although there was concern and skepticism about its implementation in practice.

How can we explain the limited role assumed by the United States as an Arctic society emerged? The shared interests of Arctic states typically revolve around the soft security and low politics issues of the environment, science, and Indigenous and northern peoples' well-being. Environmental cooperation is not viewed by states through a lens of competition for relative gains; in fact, states are perceived to benefit from whatever efforts their neighbors make to protect their own environments, or contribute to scientific understanding, irrespective of their own efforts. Because environmental and scientific cooperation in the Arctic has taken shape largely through guidelines rather than binding agreements, there have been no economic or political costs imposed involuntarily. Within these circumstances, the United States has played a more muted role in Arctic politics than is the case in regions where territorial and economic competition is more fierce.

\section{Competition or Conflict}

Of course, many have argued that the Arctic is a theatre of fierce territorial and economic competition. A narrative of competition has dogged the Arctic region in the popular media, with suggestions that the Arctic states, and especially the Arctic Five littoral states (Canada, Denmark, Norway, Russia, and the United States) have been 'racing' to claim large swathes of extended continental shelf and exploit the large deposits of hydrocarbon and mineral resources. Where viewed as a zero-sum competition, claims of Arctic exceptionalism are exposed to significant skepticism. Theory, and history, sug- 
gest that states, especially great powers such as the United States and Russia, will attempt to maximize their strategic and economic advantages when the opportunity presents itself, but will not make decisions that significantly increase the risk of conflict unless their survival is threatened. In the Arctic, where interests are largely compatible, this has meant developing a robust international society negotiated to uphold Arctic states' interests based on a set of primary and secondary institutions that foster collaboration and information sharing, while establishing a unique Arctic balance of power. When viewed through a lens of absolute gains, the five littoral Arctic states all stand to benefit from a stable, peaceful, and accessible ocean, whereas instability would threaten their economic and strategic advantages.

The Arctic Ocean is best described, not as a newly opened 'Wild West' up for grabs, but as an ocean. Like the others, it is subject to the terms of the 1982 United Nations Convention of the Law of the Sea. ${ }^{2}$ One of the most pertinent provision with regards to Arctic governance has to do with submission of claims to the outer limit of continental shelf beyond the 200-nautical mile Exclusive Economic Zone. There is an unusually far extension of geologic shelf throughout the Arctic basin (Antrim 2017), meaning lots of shelf to claim for the Arctic states through the processes identified in UNCLOS, e.g. through the Commission on the Limits of the Continental Shelf.

Following media reports of a scramble for the Arctic following the Russian planting of a titanium flag on the sea bed at the geographical North Pole in August 2007, the 'Arctic Five' states ${ }^{3}$ held a meeting in Ilulissat, Greenland, on 28 May 28, 2008 , to reassert their commitment to the existing "legal framework and to the orderly settlement of any possible overlapping claims" (Ilulissat Declaration 2008). Rather than the setting for a great power showdown, the Ilulissat Declaration demonstrated that the Arctic region had become exclusive, a club unto itself, in which the five littoral states stand to gain tremendously and seek to preserve their collective sovereignty and jurisdiction over the region, vis à vis other stakeholders. (see Jacobsen and Strandsbjerg's article in this issue which analyses the Ilulissat Declaration as a desecuritization act).

Forming a group or society of states concomitantly requires an identification of those who are not part of the club. China has previously called for the Arctic Ocean to be considered a "common heritage of mankind" (Zhuo 2010), and the EU Parliament called for an Antarctic-like Treaty to govern the region in 2008, to the dismay of the Arctic Five. Subsequently, criteria for Observership in the Arctic Council - a role with no inherent power - was devised to assess the extent to which "the applicant recognizes Arctic States' sovereignty, sovereign rights" and understands that "an extensive legal framework applies to the Arctic Ocean including, notably, the Law of the Sea, and that this framework provides a solid foundation for responsible management of this ocean" (Arctic Council 2013). China, India, South Korea, Singapore, Japan and Italy, and with

\footnotetext{
${ }^{2}$ Although the United States is not a signatory to UINCLOS, it accepts most of the Law of the Sea, including parts pertinent to the Arctic, as customary international law.

${ }^{3}$ The states with EEZs extending in to the Arctic Ocean: Canada, Denmark, Norway, Russia and Unites States.
} 
some caveats the European Union ${ }^{4}$, met these provisions to the satisfaction of the Arctic states and were finally admitted as Observers in 2013. But the Arctic Council retains a strong dynamic of those who are in and those who are out. The most recent, May 2017, Agreement on Enhancing International Arctic Scientific Cooperation was ultimately negotiated between just the eight Arctic states despite the strong scientific interests and contributions in the region by other states and their nationals (see Greaves and Pomerants article in this issue about 'soft' securitization and the Arctic Council).

It is not only non-Arctic states who have been cast as outsiders of regional Arctic society. There have been tensions with other members of the Arctic Council, namely Iceland, Finland, and Sweden, as well as some Indigenous Permanent Participants, when the Arctic Five have endeavored to meet, beginning but not ending with Ilulissat. More recently, the Arctic Five states issued a Declaration to Prevent Unregulated Fishing in the Central Arctic Ocean, on July 16, 2015. Because the Central Arctic Ocean is High Seas, the Arctic Five do not have any authority to prevent others from fishing there, and did not assume any. However, Iceland called the move "unacceptable" (Quinn 2015) and summoned the respective Ambassadors to explain why Iceland had been left out. (Talks have since expanded to include Iceland, as well as China, the European Union, Japan, and South Korea and negotiations will likely conclude in 2017.)

What is most notable of this is the demonstration that in many Arctic affairs, Russia is a normal and even preeminent member of regional society, part of the upper tier, and not an outcast as is often described or would be expected based on its relationship with the Western Arctic states elsewhere.

\section{The Manifestation of Exceptionalism}

Recent history affirms that the Arctic is exceptional, inasmuch as narratives of conflict or at least spillover, based on the confluence of antagonistic actors, an underdeveloped resource base, strategic location, and rapid change, have failed to be realized.

Russia's 2014 incursion into Crimea, and before that Georgia in 2008, has tested the Arctic states' resolve to maintain cooperative relations in the region whilst pursuing sanctions elsewhere. Regional cooperation has proven resistant however. Rather than a dissolution of Arctic society, there has been ongoing investment into the development of shared norms, rules and institutions in the past five years. These include:

- The conclusion of three binding agreements negotiated under the auspices of the Arctic Council, including the 2011 Agreement on Cooperation on Aeronautical

\footnotetext{
${ }^{4}$ The European Union is a special case. In 2013, the Arctic Council "receive[d] the application of the EU for Observer status affirmatively", but deferred a final decision, due to Canada's concern over its seal products ban. Although this particular issue was resolved by the 2015 Ministerial, Russia then blocked full acceptance due to tensions related to sanctions in the Arctic region over Crimea. In practice, the EU enjoys all of the minimal benefits Observer status offers, as an ad hoc Observer.
} 
and Maritime Search and Rescue in the Arctic; the 2013 Agreement on Cooperation on Marine Oil Pollution, Preparedness and Response in the Arctic; and the 2017 Agreement on Enhancing Arctic Scientific Cooperation.

- The establishment of a Permanent Secretariat for the Arctic Council in Tromsø, Norway in 2013, which together with the two binding agreements marked a progression in the institutionalization and authority of the Council vis à vis the Arctic states.

- The adoption of a mandatory Polar Code, or International Code for Ships Operation in Polar Waters, under the auspices of the International Maritime Organization (IMO) in 2014.

- The establishment of an eight-party Arctic Coast Guard Forum in 2015 to cooperate at an operational level in the maritime Arctic.

- A Declaration by the five littoral Arctic states Concerning the Prevention of Unregulated high Seas Fishing in the Central Arctic Ocean in July 2015, with negotiations underway to extend an agreement to China, Japan, South Korea, Iceland, and the EU in 2017.

The decision to compartmentalize relations within the Arctic from external events and factors has been a conscious one. Statements by various Arctic diplomats summarize the thinking: Canadian Senior Arctic Official Alison Leclaire asserted in October 2016 that "Canada and Russia have interests in the Arctic, including shared interests, hence the importance of engaging in interstate dialogue... despite differences on some issues, communication channels between Russia and Canada should remain open" (as quoted in TASS 2016). Norwegian Foreign Minister Børge Brende articulated in March 2017 that

\footnotetext{
"Northern regions and cooperation in the Arctic is of high priority for Norway. Russia is an important partner and player in the Arctic, and [the Arctic Dialogue conference in Arkhangelsk] provides a good frame for continuing the political dialogue with Russia regarding questions of common interests" (as quoted in Nilsen 2017).
}

Similarly, Russian President Vladimir Putin stated in March 2017 that "It is essential to preserve the Arctic as a territory of constructive dialogue, creation and cooperation on an equal basis... Russia sees no potential for conflicts in the Arctic Region" and international norms "serve as a firm basis for joint solutions of any problems" (as quoted in TASS 2017). 
The exceptionalism of Arctic society - the conscious effort to compartmentalize relations in the region - is less about idealism and more about shared interests. Events and phenomena that have proven destabilizing in other regions have not had the same effect on Arctic relations. This can be explained by fundamental differences in the Arctic region's geography and demography, and the society that has evolved within it.

Marine and Environmental Interests

Perhaps most importantly from an international relations point of view is the fact that the Arctic region is oceans-based, as opposed to land-based. This, combined with other features of the Arctic including remoteness, sparseness, and extreme weather conditions, has drastically reduced the flow of trade, people, and conflict - the issues that dominate regional relations in other parts of the world. It is no surprise, then, that formal regional cooperation - the 'procedural standards of conduct' - have occurred primarily around marine issues. ${ }^{5}$

Marine matters are particularly well suited for and benefit from regional cooperation, because water boundaries are much more fluid, literally and figuratively. Environmental matters are similar: political borders have little influence on the traversing of air, water, flora and fauna, or pollutants. The ocean-based Arctic region thus offers many benefits for cooperation to states.

\section{Epistemic Community}

Another unique characteristic of Arctic international society is the influence and composition of its epistemic community. There is an unusual amount of political space for non-state actors, particularly Indigenous organizations, scientists/academics, and environmental NGOs, perhaps because the state itself has generally had less of a presence in the Arctic.

This uniqueness is perhaps best demonstrated in the structure of the Arctic Council, which in addition to its eight state members includes six Indigenous Permanent Participants, "created to provide for active participation and full consultation" (Arctic Council 2013). Permanent Participants are fully included in the Council's executive meetings, Ministerials, Working Groups, and Task Forces. They do not have a vote per se, but as the Arctic Council is a consensus based organization, this has not had much significance. NGOs, scientists, and scientific organizations have also played a central

\footnotetext{
${ }^{5}$ Shipping, e.g. the 2015 Polar Code; SAR, e.g. 2011 Agreement on Aeronautical and Mari-time Search and Rescue in the Arctic; marine environment, e.g. 2013 Agreement on Cooperation on Marine Oil Pollution, Preparedness and Response; Coast Guards, e.g. 2015 Arc-tic Coast Guard Forum; fisheries, e.g. 2015 Oslo Declaration Concerning Prevention Un-regulated High Seas Fishing in the Central Arctic Ocean; and marine wildlife, e.g. 1973 Agreement on Conservation of Polar Bears.
} 
role in the work of the Arctic Council, e.g. in the production of its reports, assessments, and guidelines.

It can be argued that this diverse network of actors has played a stabilizing influence in regional society; there is strong path dependency towards the continuation of scientific, environmental, and Indigenous cooperation at various other levels, irrespective of the political ebbs and flows in state relations.

Likelihood of Military Conflict

The Arctic's history and geography also reduce the likelihood of conventional military conflict in the region. On the first point, the relative sparsity of the Arctic population, and the late settlement by ethnic Europeans, means that there isn't a recent history of territorial loss and boundary change across the region, at least on the part of nationstates (for Indigenous peoples the view is quite different). This is in sharp contrast to the context of Russian aggression in Crimea and South Ossetia, which were both formerly part of the Soviet Union, host large ethnic Russian populations, and maintained close relations with Moscow following its collapse in 1991 and their absorption into Ukraine and Georgia, respectively. These are narrow, specific and predictable circumstances. Based on this pattern, the Baltic states have reasonable cause to fear a Russian incursion but not the Scandinavian countries, and certainly not North America.

Other concerns about a conflict over newly accessible Arctic resources are similarly unlikely given the region's geography and geology. Over $90 \%$ of the estimated offshore hydrocarbon resources in the Arctic fall within the Arctic states' own, undisputed, Exclusive Economic Zones (EEZs), with Russia, Norway, and Alaska possessing the lion's share. There will be no case in the foreseeable future of Russia or any other country running out of Arctic hydrocarbons to extract, and so looking to annex other regions. Rather, the vast majority of Arctic offshore oil remains untapped because it is difficult and expensive to access, and thus unprofitable. Furthermore, Canada and the United States announced their intentions on December 20, 2016 to designate their respective Arctic offshores off limits for oil and gas development.

The idea of taking Arctic resources by force also defies logic. Those largescale Arctic developments that have been realized are typically multi-billion-dollar capital investments which require decades-long lifespans to reap returns. Investors do not and will not fund billion dollar Arctic projects under conditions of significant geopolitical uncertainty, for example where territory is under dispute. It is therefore in everyone's economic interest to maintain a peaceful and stable Arctic region which is rulesbased and predictable.

It is also difficult to imagine a scenario in which military tactics would serve any states' Arctic interests. The vast majority of the region is inhospitable, dangerous, and generally inaccessible. Some kind of large-scale land-based acquisition is thus inconceivable, as for the most part there is nothing to take and nowhere to occupy. As former Canadian Chief of Defense Staff, General Walt Natynczyk, articulated in 2009, 
"If someone were to invade the Canadian Arctic, my first task would be to rescue them" (as quoted in Byers 2014, 9).

Norwegian General Sverre Diesen identified the most likely scenarios for actual military conflict in the Arctic at a conference in 2008. While maintaining that "we see no threat, in the conventional military meaning of the word" of military force in the region, in theory such an event would most likely be an "air- or sea-launched raid, possibly against an objective of military or economic value, but with extraction of force as soon as desired effect had been achieved". Diesen also assessed sustained military presence in the region as more "a visible expression of national interests and claims than as a traditional military deterrent" (as quoted in Skogrand 2008, 90-94).

\section{Russia's Interests}

The case for exceptionality of Arctic society rests primarily on the close and resilient cooperation between Russia and the other seven Arctic states, despite clashes in interests elsewhere. How do we account for that?

Russia's foremost strategic interest in the Arctic is to develop its resources. Resource development has propelled the Russian Arctic to contribute as much as $20 \%$ of Russian GDP (Medvedev 2008) when oil prices are high, and over 70\% of the Arctic region's GRP (Glomsrød et al 2017, 28); Russia's Arctic produced 70\% of the country's oil and 90\% of its gas in 2012 (Glomsrød et al 2017, 62). This is in sharp contrast to Canada, Denmark, and the United States' respective 'Arctics' (defined as Canada's three territories; Greenland and Alaska), which represent $<1 \%$ of national GDP. This makes the Arctic much more important to Russia than to its potential competitors, and also makes Russia the most invested in a stable and prosperous Arctic. Russia needs foreign investment, expertise, and markets to profit from its Arctic resources, particularly with offshore oil drilling. The sanctions imposed by Western countries over Crimea have been harmful to these efforts. Outright conflict would be paralyzing.

According to Valery Konyshev and Alexander Sergunin (2014, 2), it would not make sense for Russia to "pursue a revisionist policy in the Arctic" because it is "a status quo power" in the region. Although much has been written and speculated about Russian investments in their Arctic military capabilities, they are often described as 'modernization programs' designed to retrieve some of its capabilities in the Soviet era. Konyshev and Sergunin argue $(2014,2)$ that these "programs are quite modest and aim at upgrading the Russian armed forces in the High North rather than providing them with additional offensive capabilities or provoking a regional arms race".

This is not to say that conflict in the Arctic with Russia is impossible, even as it is unlikely. However, Russia's militarization of the region appears to be more focused on domestic political interests than being outwardly aggressive. There have been no overt violations of existing agreements, no military skirmishes, and no posturing that would appear to indicate Russia, or any other Arctic state, is on the verge of initiating conflict. Rather than fearing Russia's behavior in the Arctic, it is incumbent on other 
Arctic states to engage with Russia and use the Arctic as an avenue for dialogue and cooperation, rather than to engage in arms racing behavior or escalation tactics that would erode the existing diplomatic normative character of Arctic international society.

Great Powers, English School, and Arctic Exceptionalism

Returning to Hedley Bull and the English School (Bull 2002, 200), how can we best understand persistence of peace and stability in Arctic society? The key to understanding how an international society functions, is found, as noted above, in the institutions negotiated by the states involved in a society of states, indicating their normative preferences and structure for a society at a given time in history. By examining the primary institutions of Arctic international society, the exceptional trends of the region become clearer:

1. An Arctic Balance of Power: Despite the media hype around new military investments in the Arctic, it is generally agreed that they have not fundamentally altered the regional balance power, or as George Soroka describes it, "the other regional states have not yet seen a need to balance against Moscow" (as quoted in Exner-Pirot 2017). Indeed, the United States has let much of its Arctic capabilities diminish, especially in terms of ice-breaking power. While Moscow appears to be investing more heavily, as described above it is not aimed at providing Russia with provoking a regional arms race or establishing Russia as a regional hegemon. Other Arctic states have responded by investing in their own capabilities, but not to the extent that the Arctic balance of power is predicated on balancing against Russian power in the region.

2. Arctic Diplomacy: Even though there have been difficult moments, all of the Arctic states, including the United States and Russia, have been very deliberate in articulating that the Arctic is a region of cooperation and that this must not change, which has been reinforced by their actions. In spite of economic sanctions, Arctic-specific collaboration including fisheries, shipping, scientific cooperation and SAR, has been ongoing since the annexation of Crimea, and the work of the Arctic Council has not been affected in any explicit way. Much emphasis is placed on 'dialogue' and a regional commitment to multilateralism and cooperation.

3. Emphasis on International Law: Though the Arctic Council does not discuss military matters, and the ad hoc meetings of the Arctic Chiefs of Staff were suspended after March 2014, confidence building measures such as the establishment and activities of the Arctic Coast Guard Forum have continued. Russia has been actively settling its boundary disputes, and the threat they pose to stability, with its successful delimitation of its Barents Sea maritime boundary with Nor- 
way in 2010, and through the orderly delimitation of its extended continental shelf via the Commission on the Limits of the Continental Shelf (CLCS). In fact, Russia has restricted its submission to the CLCS to the shelf largely to the eastern hemisphere, with its claim to the Lomonosov Ridge ending close to the North Pole (Russian Federation 2015). Denmark's submission, by contrast, goes deep in to the Eastern, or Russian, side (Kingdom of Denmark 2014).

4. Role of Arctic States: States remain the primary actors and decision-makers in Arctic international society, but they have consciously chosen to allow elements of world society to significantly influence decisions and multilateral bodies that are key components of the way the Arctic works. NGOs, Indigenous groups, and civil society are important actors in explaining how decisions in the Arctic are made by states, which has helped to influence the cooperative structure of the Arctic society of states.

5. War: While it is the case that narratives around Arctic conflict, competition and a 'race' for the region are exaggerated, it is important to note that the Arctic is not immune from states acting to assert or protect their interests, and that ongoing militarization of the region can affect how willing states are to maintain an institutional framework for Arctic international society based on cooperation. War has been used historically by international societies as a means of establishing and protecting order and the balance of power, and as Arctic international society continues to evolve, great power management must have the option as a means of deterring states from disrupting the institutional structure of the region and enforcing the interests of Arctic states.

\section{Conclusions}

Arctic international society has been framed as a unique, or even exceptional, region in that it has exhibited resilience to the clashing of interests that have pervaded Russia's relations with the West elsewhere during the post-Cold War period. For international relations theorists in the realist camp, this state of affairs is seen as highly tenuous, with competition and conflict stemming from unsettled boundaries, large and newly accessible reserves of oil and other resources, strategic location, and the presence of both a superpower in the United States and a revisionist great power in Russia, overdue to impact Arctic relations. This paper has argued that the English School of international relations better explains the current state of affairs in the Arctic, which continues to be marked by cooperation and stability.

The Arctic states have negotiated a rules- and norms- based order that serves all parties' interests well. A regional international society has been founded on environmental protection and marine cooperation, both issues where states seek absolute, not relative gains. It is marked by extensive non-state actor cooperation, particularly 
amongst Indigenous peoples, scientists, and NGOs, which has served to moderate the impact of fluctuations in state relations elsewhere. Russia in particular, with its economic dependence on hydrocarbon and mineral exports from its Arctic region, is vested in a stable and predictable regional order. There are no obvious strategic goals that could be accomplished through military means in the Arctic.

The establishment over the past thirty years of a robust Arctic international society has not made the region immune to inter-state competition and conflict. It is incumbent upon the Arctic states to continue to be proactive in maintaining and strengthening the values, norms and institutional framework that have made it exceptional in contemporary international relations. But there is a recognition amongst all stakeholders that the nature of regional Arctic relations is worthy of protection; as a model of international society, it is also worthy of emulation.

Bibliography

Antrim, C. (2017). Geography and Jurisdiction in the Maritime Arctic. Geographical Review, vol. 107(1), pp. 24-47.

Arctic Council. (2013). Rules of Procedure. Kiruna, Sweden. Available at: https://oaarchive.arctic-council.org/bitstream/handle/11374/940/2015-09-

01_Rules_of_Procedure_website_version.pdf?sequence $=1 \&$ isAllowed $=y$. [Accessed 21 April 2017].

Bloom, E. (1999). Establishment of the Arctic Council. American Journal of International Law, vol. 93(3), pp. 712-722.

Bull, H. (2002 [1977]). The Anarchical Society: A Study of Order in World Politics. 3rd ed. New York: Columbia University Press.

Byers, M. (2014). Does Canada Need Submarines?. Canadian Military Journal, vol. 14(3), pp. 7-14.

English, J. (2013). Ice and Water. Toronto: Penguin Books.

Exner-Pirot, H. (2017). Interview with George Soroka: Russia's Reimagined Arctic. World Policy. Available at:

http://www.worldpolicy.org/blog/2017/03/15/russia\%E2\%80\%99s-reimaginedarctic. [Accessed 22 April 2017].

Fawcett, L. and Hurrell, A. (eds.). (1996). Regionalism in World Politics: Regional Organization and International Order. Oxford: Oxford University Press.

Glomsrød, S., Duhaime, G. and Aslaksen, I. (eds.). (2017). The Economy of the North 2015. Statistics Norway, Oslo. Available at: https://www.ssb.no/en/natur-ogmiljo/artikler-og-publikasjoner/_attachment/299576?_ts=15aea97d740. [Accessed 21 April 2017].

Gorbachev, M. (1987). Speech in Murmansk at the Ceremonial Meeting on the Occasion of the Presentation of the Order of Lenin and the Gold Star to the City of 
Murmansk

(transcript).

Available

at:

https://www.barentsinfo.fi/docs/Gorbachev_speech.pdf. [Accessed 19 December 2016].

Heininen, L. (2012). State of the Arctic strategies and policies-a summary. Arctic Yearbook, 2012, pp. 2-47.

Huebert, R. (1998). New directions in circumpolar cooperation: Canada, the arctic environmental protection strategy, and the Arctic Council. Canadian Foreign Policy Journal, vol. 5(2), pp. 37-57.

Ilulissat Declaration. (2008). Available at: http://www.oceanlaw.org/downloads/arctic/Ilulissat_Declaration.pdf [Accessed 18 December 2016].

Jackson, R. (2000). The Global Covenant: Human Conduct in a World of States. Oxford: Oxford University Press.

Keskitalo, E.C.H. (2004). Negotiating the Arctic: The Construction of an International Region. New York: Routledge.

Kingdom of Denmark. (2014). The Northern Continental Shelf of Greenland: Partial Submission to CLCS. Available at: http://www.un.org/depts/los/clcs_new/submissions_files/dnk76_14/dnk2014_e s.pdf. [Accessed 22 April 2017].

Kingdom of Denmark, Canada, Norway, Russian Federation and United States of America. (2007). The Illulissat Declaration. Available at:

http://www.arcticgovernance.org/the-illulissat-declaration.4872424.html. [Accessed 29 August 2017].

Konyshev, V. and Sergunin, A. (2014). Is Russia a Revisionist Military power in the Arctic?. Defense and Security Analysis, vol. 30(4), pp. 323-335.

Medvedev, D. as quoted in RT. (2008). Russia defines its slice of Arctic. Available at: https://www.rt.com/news/russia-defines-its-slice-of-arctic/ [Accessed 21 April 2017].

Nilsen, T. (2017). New diplomatic smiles for Arctic Cooperation. The Barents Observer. Available at: https://thebarentsobserver.com/en/arctic/2017/03/newdiplomatic-smiles-arctic-cooperation [accessed 20 April 2017].

Quinn, E. (2015). Iceland Blasts Arctic Five for Exclusion from Fishing Agreement. Eye on the Arctic. Available at: http://www.rcinet.ca/eye-on-the$\operatorname{arctic} / 2015 / 07 / 30 /$ iceland-blasts-arctic-five-for-exclusion-from-fishingagreement/ [Accessed 16 December 2016].

Russian Federation. (2015). Partial Revised Submission of the Russian Federation In respect of the Continental Shelf. Available at: http://www.un.org/depts/los/clcs_new/submissions_files/rus01_rev15/2015_08 _03_Exec_Summary_English.pdf[Accessed 22 April 2017].

Skogrand, K. (2008). Emerging from the Frost: Security in the 21 st Century Arctic. Oslo Files on Defence and Security, Norwegian Institute for Defence Studies, Oslo. 
Stivachtis, Y. (2015). Shifting Gears: From Global to Regional - The English School and the Study of Sub-Global International Societies. In: R. W. Murray (ed.). System, Society and the World: Exploring the English School of International Relations. $2^{\text {nd }}$ ed. Bristol: E-International Relations, pp. 68-86.

TASS. (2017). Putin Urges to Preserve Arctic as Territory of Dialogue. Available at: http://tass.com/world/938424 [Accessed 20 April 2017].

TASS. (2016). Canadian foreign ministry official: Canada, Russia have shared tasks in the Arctic, dialogue important. The Arctic. Available at: http://arctic.ru/international/20161125/504287.html [Accessed 20 April 2017].

Weinert, M. (2014). Sovereignty as an Institution of International Society. In: R. W. Murray and A. D. Nuttall (eds.). International Relations and the Arctic: Understanding Policy and Governance. Amherst: Cambria Press, pp. 79.104.

Waltz, K. (1979). Theory of International Politics. New York: McGraw-Hill.

Wight, M. (1978). Power Politics, edited by Hedley Bull and Carsten Holbraad. London: Royal Institute of International Affairs.

Young, O. (1992). Arctic Politics: Conflict and Cooperation in the Circumpolar North. Hanover: University Press of New England.

Zhuo, Y. as quoted in The Hindu (2016). India's stake in Arctic Cold War. Available at: http://www.thehindu.com/opinion/op-ed/Indias-stake-in-Arctic-coldwar/article13290404.ece [Accessed 29 August 2017]. 